\title{
Introduction: The private life of the employee in comparative case law
}

\section{Allison Fiorentino}

\section{(2) OpenEdition}

1 Journals

\section{Electronic version}

URL: https://journals.openedition.org/rdctss/851

DOI: $10.4000 /$ rdctss.851

ISSN: 2262-9815

\section{Publisher}

Centre de droit comparé du travail et de la sécurité sociale

\section{Printed version}

Date of publication: 1 December 2020

Number of pages: 134-141

ISSN: 2117-4350

\section{Electronic reference}

Allison Fiorentino, "Introduction: The private life of the employee in comparative case law", Revue de droit comparé du travail et de la sécurité sociale [Online], 4 | 2020, Online since 01 December 2020, connection on 26 January 2022. URL: http://journals.openedition.org/rdctss/851 ; DOI: https://doi.org/ $10.4000 /$ rdctss. 851

\section{(c) (i) (9)}

Revue de droit comparé du travail et de la sécurité sociale est mise à disposition selon les termes de la Licence Creative Commons Attribution - Pas d'Utilisation Commerciale - Pas de Modification 4.0 International. 


\title{
INTRODUCTION: THE PRIVATE LIFE OF THE EMPLOYEE IN COMPARATIVE CASE LAW
}

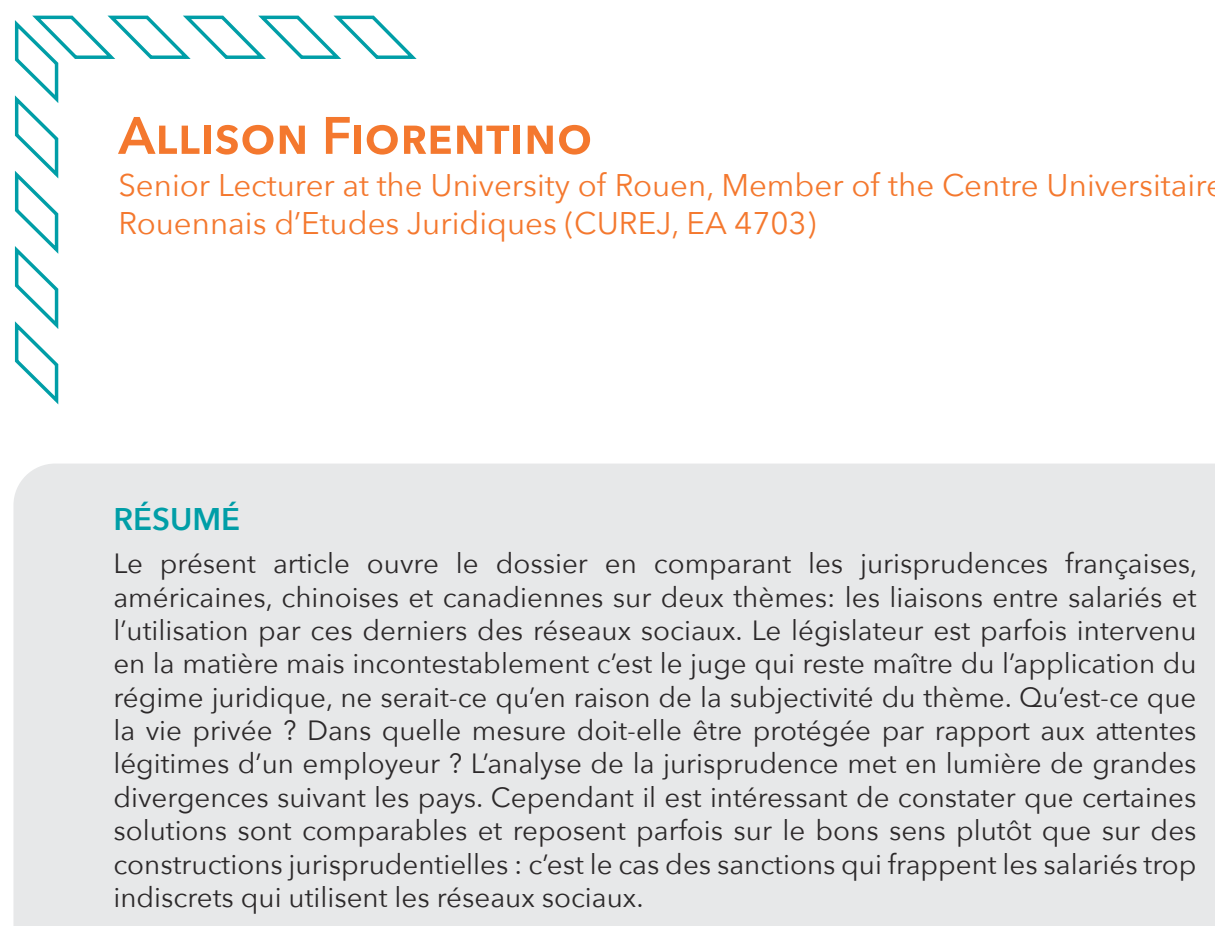

Mots clés : Réseaux sociaux, liaison, intimité, diffamation, liberté d'expression

\begin{abstract}
This article opens the chronicle by comparing French, American, Chinese and Canadian case law on two themes: affairs between employees and their use of social networks. The legislator has sometimes intervened in this matter, but it is unquestionably the judge who remains in control of the application of the legal system, if only because of the subjectivity of the subject. What is privacy? To what extent must it be protected in relation to an employeris legitimate expectations? An analysis of the case law reveals wide divergences between countries. However, it is interesting to note that some solutions are comparable and are sometimes based on common sense rather than on jurisprudential constructions: this is the case of sanctions against overly indiscreet employees who use social networks.
\end{abstract}

Keywords: Social Networks, Liaison, Intimacy, Defamation, Freedom of Expression 


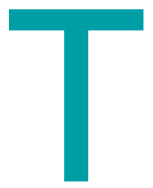

o what extent can the employee's privacy be protected? Private life and professional life are sometimes inextricably intertwined and ultimately opposed. Indeed, the employee, like any individual, can claim the right to a certain intimacy, but the delimitation of this intimacy implies determining the boundaries that the employer cannot cross. This is not an easy thing to do, if only because the cases of tension are very numerous.

The issue of the employee's privacy necessarily impacts the tests that the employer may undergo: drug testing, obtaining the employee's credit history, HIV testing, genetic testing, criminal background checks, psychological tests, etc. The issue of employee surveillance is also crucial : monitoring the use of computers, telephones and electronic devices to locate employees, searching offices and workplaces, or using video surveillance devices. Finally, other problematic situations for the company may be linked to the employee's claim to privacy: freedom of clothing, emotional relations with another employee.

These various examples inevitably highlight the tension between two contradictory sets of principles. On the one hand, there is the principle of the inviolability of the employee's right to privacy. On the other hand, there is the right of the employer to enjoy his property and to exercise his managerial powers to protect his property against potential abuse by his employees. The legitimacy of these respective claims is undeniable, but the question of balance is delicate and requires all the delicacy of a praetorian work. Indeed, only the judge is confronted with pragmatic situations that will lead him to balance private life and property rights. The purpose of this series of articles is to highlight the importance of the case law in the search for this balance.

The multitude of situations in which a confrontation between these two principles is inevitable makes it difficult to elaborate an exhaustive panorama on the question of the employee's private life in comparative law. It therefore seems relevant to begin the analysis of this chronicle with two examples: the consensual relationship between employees (French and American case law) (I) and the use by employees of social networks (Chinese and Italian decisions) (II).

\section{I - DANGEROUS LIAISONS IN FRENCH AND AMERICAN LABOR LAW}

The situation referred to here is that of purely consensual relations between two employees. This therefore excludes cases of harassment, which would constitute a fault and justify dismissal. A love affair in the workplace, however discreet it may be, is not without risk for the employee. Two antagonistic judicial positions can be used: that of the French judge and that of his American counterpart.

In France, the employee undoubtedly benefits from an advantage based on two texts. On the one hand, Article 9 of the Civil Code states that «Everyone has the right to respect for his or her private life ", immediately excluding the interference of an employer in a love relationship that does not generate any disturbance in the company. In addition, Article L. 
1132-1 of the Labor Code prohibits any direct or indirect discrimination « on the basis of morals or sexual orientation (...) or family status (...)». The love relationship is not expressly covered, but this article could extend its scope of protection to sentimental life in general.

In 2006', the French Supreme Court ruled that there was no real and serious cause for the dismissal of a supermarket cashier due to an affair with a colleague. Without resorting to the notion of discrimination, the judge had noted that the employer could not claim a sufficient disturbance to infringe on the employee's private life. Thus, Professor Radé emphasized: "Because they are part of the intimacy of private life, feelings must be protected and remain in the private sphere $»^{2}$.

However, this protection for the employee is not absolute. If the relationship has a negative impact on the company, the employer has the right to intervene. First of all, since the 1990s, the French courts have developed case law on the notion of objective disturbance to the functioning of the enterprise ${ }^{3}$. This notion of « objective disturbance " is assessed with regard to the activity of the firm and the nature of the employee's duties, the notoriety of the employee's act or its repercussions on the firm. Using the technique of the bundle of indices, the judge decides, on a case-by-case basis, whether the action of an employee in his private life may constitute a cause for dismissal, the latter being then not faulty. This jurisprudence is applicable in matters of the employee's love relationship.

Thus it was judged that the dismissal of an employee was justified since the latter had hit his concubine, also an employee ${ }^{4}$. The altercation had taken place outside the workplace, but the police had intervened in the company to arrest the violent partner. The objective disorder was characterized.

In addition to the objective disorder, another situation may justify dismissal, this time disciplinary: when the relationship reflects a failure on the part of one of the employees to meet his or her professional obligations. The decision of September 25, $2019^{5}$ is an illustration of this. The facts were comical. A hierarchical superior has a relationship with a subordinate and exchanges SMS messages with her. However, the romance is spoiled when the employee does not get the benefits she wants and complains to management about sexual harassment. The Social Chamber, relying on the consensual nature of the relationship (established by the SMS), ruled out harassment and therefore the employee's serious misconduct, but nevertheless validated the disciplinary dismissal on the grounds that this relationship had caused him « to lose all authority and credibility in the exercise of his management function [...] incompatible with his responsibilities", so that « these facts were related to the life of the company and could justify a disciplinary dismissal».

It can be seen that the protection of the employee's private life is an obstacle to any retaliation by the employer (except in exceptional cases). The situation in American law is the opposite. Professor Matthew W. Finkin, a great specialist in this question (whose work we

1 Cass. Soc. 21 december 2006, no. 05-41140.

2 C. Radé, «Amour et travail : retour sur un drôle de ménage », Dr. soc., 2010, p. 35, spec., p. 39.

3 P. Waquet, "Le 'trouble objectif dans l'entreprise' : une notion à redéfinir », RDT Dalloz, 2006, p. 304; P.-H. Antonmattei, « Le licenciement pour trouble objectif », Dr. Soc., 2012, p. 10.

4 Cass. Soc. 9 july 2002, no. 00-45.068; B. Bossu, « Une altercation avec sa concubine peut justifier le licenciement d'un salarié », RJPF, 2003, no. 2, p. 9.

5 Cass. Soc. 25 sept. 2019, no. 17-31.171, Gaz. Pal, 3 dec. 2019, no. 42, note S. Harir ; Bulletin Trav., 2019, no. 11, p. 22, note J. Icard. 
publish in this chronicle) had written: «As far as employee privacy is concerned, the United States is, legally speaking, an underdeveloped country compared to a large part of Europe $»^{6}$. If the days when Henry Ford inspected workers' homes are over ${ }^{7}$, employers have never

encountered an obstacle comparable to Article 9 of the French Civil Code because there is no equivalent in American law.

In the United States, workers have very few legal protections for privacy. Few situations exist where an employee has the right, under due process of law, to access, inspect or challenge information collected or held by the employer. There is a patchwork of federal and state laws that grant employees limited rights $^{8}$. For example, the Electronic Communications Privacy Act of 1986 (ECPA) is the only federal law that provides workers with protections for the confidentiality of communications. The ECPA prohibits the intentional interception of electronic communications?.

These exceptions are by no means an effective means of protecting the privacy of employees, and quite logically it follows that the employer can interfere in the intimate life of his subordinates. It is possible for him to prohibit any love relationship in the workplace. Such a prohibition would encounter two obstacles in France: on the one hand, the principle of protection of privacy and, on the other hand, the right of the French judge to decide whether a ground for dismissal is real and serious. However, under U.S. law, an employee may be dismissed for any reason as long as a specific law does not prohibit that reason. This is the principle of employment at will ${ }^{10}$.

This managerial freedom therefore makes it possible to dismiss two employees who would have maintained an affective relationship, even a consensual one. One of the examples frequently cited is the case of UPS against one of its employees, who was dismissed for this reason ${ }^{11}$. The love affair between two employees of this company had remained secret for four years and had not had a negative impact on the company. Moreover, it had ended in marriage. However, the affair had begun in violation of the general prohibition against UPS employees having such an affair, and it was for this reason alone that one of the employees had been dismissed. Despite his appeal, no compensation was awarded to him. The judge ruled that the employer had not violated any law. It would have been different if the employee had been able to use a law prohibiting discrimination on the basis

6 M. W. Finkin, "Some further thoughts on the usefulness of comparativism in the law of employee privacy », Employee Rts. \& Emp. Pol'y J., 2010, vol. 14, no.1, spec., p. 11.

7 J.Cunningham Wood and M. C. Wood, Henry Ford: Critical Evaluations in Business and Management, Vol. 1, Taylor \& Francis, 2003, p. 163.

8 M. W. Finkin, Privacy in Employment Law, Bloomberg Law, 5e ed., 2018.

9 However, the ECPA contains loopholes that make it easier to control employees. First, employers are allowed to monitor networks for business purposes. This allows them to listen in on employees' phone calls or check their e-mails. Employers cannot monitor purely personal calls. However, in order to determine whether a call is personal, employers generally must listen to certain parts of the employee's conversation. Second, an employer may intercept communications where there is consent - real or implied - from the employee. Consent exists when the employer merely gives notice of the surveillance.

10 A. Fiorentino, «Le licenciement en droit américain : le principe fondamental de l'employementat-will et sa portée contemporaine ", Revue de la recherche juridique. Droit prospectif, 2012, no. 1, p. 463.

11 Ellis v. United Parcel Serv., Inc., 523 F.3d 823 (7th Cir. 2008). 
of personal life. Such a law does not exist in the United States and at most some states prohibit discrimination on the basis of marital status ${ }^{12}$. Moreover, the petitioner could not have benefited from it since it was not his marriage that had caused the dismissal.

\section{II - SOCIAL NETWORKS AND LABOUR LAW IN CHINESE AND CANADIAN JURISPRUDENCE}

In this case, the oppositions between jurisprudence are less clear-cut ${ }^{13}$. It seems that the notion of private life (whether or not it has been explicitly recognized for the benefit of employees) is set aside when the employee commits the imprudence of making certain information public.

In China, there has been little legislation or regulation specifically addressing employee privacy issues on the Internet in the workplace context. A patchwork of somewhat relevant rules and principles has developed, piecemeal fashion, resulting in low obligations for employers and significant gaps in employee protection ${ }^{14}$. The Chinese Constitution does not specifically refer to a right to privacy. Article 34 provides that the personal dignity of the citizen is protected as a fundamental right. Article 40 protects the privacy of citizens' correspondence, which would presumably cover correspondence on social media. However, the constitutional provisions are not directly applicable and cannot be used in a trial involving two private persons.

It was not until the Law on Civil Liability, introduced in 2009, that the right to privacy was recognized as one of the rights enjoyed by an individual, the violation of which constitutes a tort subject to prosecution ${ }^{15}$. The new general civil law provisions of 2017 further expand the protection of privacy rights by placing it alongside other human rights. Article 110 states the following: «A physical person enjoys the rights to life, inviolability and integrity of the person, health, name, image, reputation, honor, privacy and marital autonomy, among others ».

To date, Labour jurisprudence is based mainly on another provision: Article 39 of the Employment Contracts Act, according to which the employee's fault must be serious in order for the employer to justify immediate dismissal without compensation. These circumstances include cases where the employee has seriously violated the rules and procedures established by the employer, has caused significant harm to the employer due to gross neglect of duty or seeking private benefits, has simultaneously entered into an employment relationship with another employer that seriously affects his or her current employment, or is the subject of a criminal investigation.

On the basis of this text alone, three lines of case law can be identified:

- The first type of decision relates to the dismissal of the employee for having put certain information on social networks online. For example, in 2013 ${ }^{16}$, an employer dismissed

12 This is the case in California (California Fair Employment and Housing Act), Alaska (Alaska Human Rights Law) and Delaware (Delaware Discrimination in Employment Act).

13 On this subject, see the special issue on case law on the subject : Revue de droit comparé du travail et de la sécurité sociale, 2014/2, p. 88.

14 M. Zou, "Social Media and Privacy in the Chinese Workplace: Why One Should Not Friend Their Employer on WeChat », Comparative labor law and policy journal, 2018, vol. 39, no. 2, p. 389.

15 Op. cit.

16 Chen c. Di Nuo Wei Ya International Freight Forwarders (Shanghai) Co., Ltd. 
an employee for unauthorized absence from work for more than eight days. During the proceedings, the employer produced data published by the employee on his Weibo page, showing him sunbathing on a date when the employer had not given him authorization for the absence. The judge admitted the admissibility of this evidence. Another category of cases relates to criticisms made by employees against their colleagues or management.

- In a 2015 decision ${ }^{17}$, an employee had signed an agreement with his employer that, in the event of dissolution of his employment contract, he would receive compensation if he refrained from making comments that could damage the employer's reputation. Shortly before leaving his job, the employee posted a comment on his Weibo account indicating that the employer was making frequent payroll deductions. The employer claimed that the employee's comment had seriously damaged his reputation, which justified the refusal to pay him any money after his termination. The employee argued that there was no malicious intent, especially since this information was proven. The judge ruled in favour of the employee, not on the basis of the truthfulness of the information given, but on the illegality of such compensation. Indeed, it was not up to the parties to decide on the compensation required in case of dismissal, since the law protected the employee's right to such compensation. It is regrettable that the judge did not take this opportunity to clarify the case law on the matter, and to affirm - or invalidate - the right of an employee to communicate accurate information about his company.

- On the other hand, and this is the third jurisprudential trend, when the information is false and obviously proceeds from an intention to harm, the judge legitimately shows severity towards the employee who defames his employer. In a 2016 case $^{18}$, a teacher dismissed for incompetence had posted derogatory comments about the school in his WeChat groups. His comments consisted of accusations that the plaintiff did not offer appropriate qualifications, issued false diplomas, and paid himself a large portion of the salaries of students on internships. In court, the plaintiff argued that the defendant's claims were false and had led several students to withdraw their enrollment from the school, with many other students considering similar actions. The court ordered the defendant to publish a written public apology and to pay damages.

Moreover, in Canada, even if the judicial solutions vary, they highlight the lack of protection for the employee who is too imprudent to remain discreet about certain information.

Thus, in Quebec, the employee has a duty of loyalty to the employer - under article 2088 of the Civil Code of Quebec - according to which he is required to act loyally and honestly in the course of his employment, and even outside working hours when the employer's reputation and private life are at stake. Thus, the employer is entitled to expect the employee to refrain from posting comments harmful to the company's reputation. In addition, employees are entitled to freedom of expression under the Quebec Charter of Human Rights and Freedoms ${ }^{19}$. The balance that the Quebec judge struck between these two principles illustrates his desire to protect the company by easily identifying a breach of the duty of loyalty. However, if the judge admits the existence of a fault, the sanction of dismissal is sometimes censured.

17 Beijing Bonatongcheng Technology Co., Ltd. c. Li Chennan.

18 Xi'an Mou Gong Ye Xuexiao c. Tang.

19 http://www.cdpdj.qc.ca/fr/formation/situations/Documents/fr/CharteResumeSimplifiee.pdf 
Three examples illustrate this point:

- An administrative officer from the City of Montreal's human resources department was fired for posting negative comments on Facebook about the director's decision to euthanize a pit bull after it attacked citizens. However, his dismissal was reduced to a six-month suspension ${ }^{20}$.

- A city official was fired for posting on Facebook a video of an offensive song he had composed himself, with lyrics subtly targeting the Director of Technical Services and the Mayor. The video ended with a degrading gesture. His dismissal was reduced to a six-month suspension ${ }^{21}$.

- A bookstore clerk was suspended for posting defamatory comments, damaging the employer's reputation, on his blog accessible via Facebook. The articles invited readers to file online complaints against his employer and were critical of the organization's values. His three-day suspension was confirmed ${ }^{22}$.

In Ontario, the judge also strikes a balance using the cluster of indicia, as demonstrated in a 2014 decision ${ }^{23}$. A Toronto firefighter was fired for posting offensive tweets from his personal Twitter account. In reaching his decision, the judge focused largely on the sexist, racist and homophobic content of the tweets and how it negatively impacted the employer. This was exacerbated by the nature of the employee's role, as firefighters occupy a position of trust within the society and must be held to a higher standard of conduct.

In addition to the content of the messages posted on social media and the nature of the employee's position, the judge highlighted a number of judicial clues:

- Who was the audience for the posted message?

- Which platform was used?

- What were the details of the platform (e.g. privacy settings)?

- How long had the employee been employed?

- What was the employee's reaction to the discovery of the messages (repentant or not)?

These few examples highlight all the diversity of the judicial approach on the issue of employee privacy. Sometimes the solutions are opposed, sometimes they are the same even if the legal bases are different. In order to present certain laws in a more complete manner, this chronicle brings together the work of researchers from very different backgrounds.

Anglo-Saxon law will be addressed through :

- the study in Canadian law of Professor Urwana Coiquaud devoted to the question of employee tattooing;

- Professor Gabrielle Golding's analysis of Australian case law on the use of social networks by employees;

20 Montréal (Ville) and Syndicat des fonctionnaires municipaux de Montréal (SCFP-429) (Levasseur), Re, 2014 CarswellQue 14102 (T.A. Qué.).

21 (Municipalité) and Syndicat des travailleuses et travailleurs de la municipalité de Weedon (CSN) (2015-03), Re, 2016 CarswellQue 3584 (T.A. Qué.).

22 Librairie Renaud-Bray inc. and Syndicat des employées et employés professionnels-les et de bureau, section locale 574 (SEPB-CTC-FTQ) (Beauregard), Re, 2017 CarswellQue 3294 (T.A. Qué.).

23 Toronto (Clty) v Toronto Professional Fire Fighters Association, Local 3888, 2014 CanLII 76886 (ON LA). 


\section{COMPARATIVE LABOUR CASE LAW}

- the article by Professor Peter Upson on drug testing in the workplace in New Zealand law; - the overview prepared by Professor Matthew W. Finkin's on employee privacy in the United States.

The chronicle will continue with a study of a South American country, Mexico, where Professor Gabriela Mendizabal Bermudez will present the jurisprudence on the organization of working time to make it compatible with family life.

The Middle East will be considered through the work of Professor Melda Sur who will present the personal life of the employee in Turkish jurisprudence.

Finally the European law will close this file, since the following will be discussed:

- German judicial law relating to the question of the employee's dismissal for a personal activity that causes prejudice or inconvenience to the company. Professors Marie-Cécile Escande-Varniol and Gerhard Binkert carried out this work;

- Russian jurisprudence in the light of international standards concerning the employee's private life by professors Elena Serebryakova and Elena Sychenko;

- the Spanish reform of 2019 affecting the reconciliation between work and family life by professors Mercedes Lopez Balaguer and Emma Rodriguez Rodriguez;

- a reminder of the French jurisprudence on the respect of personal life in the workplace and during working hours through the inspection of the employee's computer files by Sébastien Ranc. 